\title{
Phytoplanktonic diversity in lake Jaisamand, Rajasthan (India)
}

\author{
Vijay Kumar Balai ${ }^{1}$, L. L. Sharma ${ }^{1}$ and N. C. Ujjania ${ }^{2^{*}}$ \\ ${ }^{1}$ College of Fisheries, Maharana Pratap University of Agriculture and Technology, Udaipur- 313001(Rajasthan), \\ INDIA \\ ${ }^{* 2}$ Department of Aquatic Biology, Veer Narmad South Gujarat University, Udhana Magdalla Road, Surat- 395007 \\ (Gujarat), INDIA \\ *Corresponding author. E-mail: ncujjania@yahoo.com \\ Received: September 17, 2014; Revised received: June 18, 2015; Accepted: July 26, 2015
}

\begin{abstract}
The present study describes the diversity of phytoplankton in the lake Jaisamand of Rajasthan (India). Results depict that phytoplankton was contributed by six major groups which comprised total 85 species. Out of which 13 belongs to Myxophyceae, 5 to Euglenophyceae, 38 to Chlorophyceae, 3 to Xanthophyceae, 1 to Cryptophyceae and 23 to Bacillariophyceae. Thus, Bacillariophyceae and Chlorophyceae turned up as the dominant groups in terms of density (159-554 numbers per liter and 24-485 numbers per liter) and species number (23 and 38), respectively. It was revealed that Jaisamand Lake maintained fairly good population of phytoplankton which is indication of providing broad base for achieving high productivity in this water body.
\end{abstract}

Keywords: Bacillariophyceae, Chlorophyceae, Jaisamand, Phytoplankton, Rajasthan

\section{INTRODUCTION}

The phytoplankton are the important components of aquatic ecosystem and contributing to the bulk of total primary productivity by producing organic matter which is the base of complex aquatic food webs. Further, the composition and abundance of phytoplankton can reflect the nutritional status and trophic condition of the water body within the stipulated period of time (Busing, 1998; Diazpardo et al., 1998). Besides aquatic plants, Phytoplankton is primary biological component from which the solar energy is transferred to higher organisms through various trophic levels of aquatic food chain (Tiwari and Chauhan, 2006; Tas and Gonulo, 2007 and Shashi shekher et al., 2008). For these obvious reasons therefore, phytoplankton is often used to estimate the potential fish yields (Hecky and Kling, 1981), productivity (Park et al., 2003), water quality (Walsh et al., 2001), energy flow (Simciv, 2005), trophic status (Reynolds, 1999) and management measures (Beyruth, 2000) of any water body. Furthermore, the seasonal fluctuations and species composition of phytoplankton in any water body depend on levels of light, temperature, nutrients, grazing pressure, onset of parasitic infections, extracellular metabolites of plants and animals with changing season during the year (Agrawal, 1999). Pawar et al. (2006) elucidated that study of plankton can be a very useful tool for the assessment of biotic potential thereby contributing to the overall assessment of basic nature and general economic potential of water body. The phytoplankton diversity and its importance were also described by Vaulot
(2001), Pongswat et al. (2004), Kemdirim (2001), Millman et al.(2005), Sridhar et al.(2006), Senthilkumar and Sivakumar (2008), Ganai et al. (2010), Jagad eeshappa and Kumara (2013) and Chopra et al. (2013). The focus of the current study was to estimate the variability in phytoplankton throughout the year in terms of its distribution, abundance and diversity to assess the fishery potential of lake Jaisamand.

\section{MATERIALS AND METHODS}

Study area: Jaisamand is considered as one of the oldest manmade lake as it was constructed during the year $1729 \mathrm{AD}$ by putting an embankment across the Gomti River near the village Veerpura in Udaipur district of Rajasthan state. In this lake nine rivers and several seasonal cannels (Nalahas) are emptying. For wide area coverage three sampling stations (A, B and C) were selected (Fig. 1). The morphometric details of the water body illustrated in Table 1 .

Sample collection: For the present study samples were collected at monthly intervals from three preselected sampling stations during July 2005 to June 2006. For the sample collection 100 liters of surface water was filtered with bolting silk No. 25 and the filtered plankton concentrate was immediately preserved in Lugol's solution.

Sample analysis: The preserved phytoplankton samples were transported to Research laboratory, College of Fisheries (Maharana Pratap University of Agriculture and Technology), Udaipur (Rajasthan) for quantitative and qualitative analyses. For the quantitative analysis, plankton concentrate was diluted in a beaker and one 
ml of sub-sample was taken in a Sedgwick-rafter plankton counting cell with the help of a plankton pipette. Counting of phytoplankton was done under Carl Zeiss Inverted Microscope as per the method explained in APHA (1989). The total numbers of phytoplankton were counted in each sub-sample and multiplied with dilution factor and results are expressed as number per liter. For the qualitative analysis, the phytoplankton was identified up to the species level and it was done following Needham and Needham (1962), Edmondson (1965), Subrahmanyan (1971) and Adoni (1985)

\section{RESULTS AND DISCUSSION}

During the present study, total number of phytoplankton was observed to vary between 64-2029 number per liter whereas, the seasonal variation in phytoplankton density depicted that Bacillariophyceae, Myxophyceae and Cryptophyceae were high during the monsoon (July-October) and pre-monsoon (March-June). These were however, low during the post-monsoon (November-February). The density of Chlorophyceae, Xanthohyceae and Euglenophyceae was high during post-monsoon and low during the monsoon and pre-monsoon periods (Fig. 2). These quantitative estimations further show that distributional trend of phytoplankton remained almost same throughout the study period considering all the three sampling stations. Bacillariophyceae emerged as the most dominant group by contributing $35 \%$ to the total phytoplanktonic community (Fig. 3).

The trends of seasonal density of phytoplankon observed in the present study corroborates with findings reported by Lashkar and Gupta (2009), Hassan et al. (2010), Gayathri et al. (2011), Jagadeeshappa and
Kumar (2013) and Yilmaz (2013). SenthiKumar and Siva Kumar (2008) identified total 160 species of phytoplankton in Veeranamlake in Tamil Nadu with bacillariophyceae being the dominant group. The phytoplankton density was high during summer season and low during the winter season. Lashkar and Gupta (2009) recorded total 34 phytoplankton, belonging to cyanophyceae, chlorophyceae, bacillariophyceae and euglenophyceae in Chatla flood plain lake, Barak Valley Assam. They found highest number of species (29) in pre-monsoon and lowest (23) in winter. The density of phytoplankton reported for Jaisamand by Sarang et al. (2002) was 20 to 214 (number per liter). In the present study, however, the mean phytoplanktonic abundance was relatively higher in surface water. This observed discrepancy could be due to varying grazing pressure by the prevailing fish stock and especially exotic omnivore Tilapia occurring in abundant quantity in this lake.

The minimum number of bacillariophyceae was (159 per liter) found in November-December, 2005 at station $\mathrm{B}$ and maximum number was (554 per liter) found in September- October, 2005 at station C (Fig. 2). Chlorophyceae was second dominant group with the contribution of $33 \%$ (Fig. 3), where the minimum number was (24 per liter) observed during the month of May-June, 2006 and maximum number was (485 per liter) during November-December, 2005 at the stations B and C, respectively (Fig. 2). Myxophyceae turned up as the third prominent group in the phytoplankton with $16 \%$ contribution and it was minimum $\left(8\right.$ No. $\left.^{-1}\right)$ during March-April, 2006 at station $\mathrm{C}$ while maximum number (463 per liter) was found during July-August, 2005 at Station A (Fig. 2 and Fig. 3). Xanthophyceae was the fourth group and contributed $10 \%$ of total

Table 1. Morphometric features of Jaisamand lake.

\begin{tabular}{cll}
\hline S.N. & Morphometric features & Morphometric values \\
\hline 1. & Location & $24^{\circ} 14^{\prime} \mathrm{N}$ \\
& Latitude & $73^{\circ} 57^{\prime} \mathrm{E}$ \\
& Longitude & $587 \mathrm{~m}(\mathrm{MSL})$ \\
2. & Altitude & $627.7 \mathrm{~mm}$ \\
3. & Annual rainfall & $1127 \mathrm{sq} . \mathrm{m}$ \\
4. & Catchment area & $7,160 \mathrm{ha}$ \\
5. & Area (FRL) & $32 \mathrm{~m}$ \\
6. & Maximum depth & $15 \mathrm{~m}$ \\
7. & Mean depth & 0.469 \\
8. & Mean depth/Maximum depth & $8.05 \mathrm{~km}$ \\
9. & Maximum breadth & $13.60 \mathrm{~km}$ \\
10. & Maximum length & $89.4 \mathrm{~km}$ \\
11. & Length of shoreline (L) & 3.75 \\
12. & Shoreline development index (DL) & $335 \mathrm{~m}$ \\
13. & Length of dam & $31.4 \mathrm{~m}$ \\
14. & Width of dam & $40.16 \mathrm{~m}$ \\
15. & Height of dam & Earthen and masonry \\
16. & Type of dam & Sarada \\
17. & Tehsil & $58 \mathrm{~km}$ from Udaipur city (Rajasthan) \\
18. & Accesses &
\end{tabular}


Table 2. Diversity of phytoplankton in Jaisamand lake.

\begin{tabular}{|c|c|c|c|}
\hline A. & Myxophyceae & 25. & Closterium liebleinii \\
\hline 1. & Anacystis cyanea & 26. & Cosmarium granatum \\
\hline 2. & Gomphosphaeria sp. & 27. & Ulothrix sp. \\
\hline 3. & Nostoc sp. & 28. & Microspora sp. \\
\hline 4. & Anabaena sp. & 29. & Hormidium subtile \\
\hline 5. & Rivularia sp. & 30. & Spirogyra sp. \\
\hline 6. & Phormidium sp. & 31. & Protococcus sp. \\
\hline 7. & Oscilllatoria tenuis & 32. & Cladophora sp. \\
\hline 8. & Oscillatoria rileyi & 33. & Oedogonium sp. \\
\hline 9. & Spirulina sp. (Major) & 34. & Chlamydomonas sp. \\
\hline 10. & Merismopedia sp. & 35. & Eudorina sp. \\
\hline 11. & Cylindrospermum sp. & 36. & Pandorina sp. \\
\hline 12. & Candelabrum spinulosum & 37. & Penium polymorphum \\
\hline 13. & Microcystis aeruginosa & 38. & Oophia amblystomatis \\
\hline C. & Euglenophyceae & E. & Xanthophyceae \\
\hline 1. & Euglenopsis vorax & 1. & Botrydiopsis sp. \\
\hline 2. & Heteronema sp. & 2. & Botryococcus sp. \\
\hline 3. & Gloeomonas ovalis & 3. & Tribonema bombycium \\
\hline 4. & Polytoma uvella & F. & Cryptophyceac \\
\hline 5 & Platydorina sp. & 1. & Cyanomonas coeruleus \\
\hline D. & Chlorophyceae & G. & Bacillariophyceae \\
\hline 1. & Volvox sp. & 1. & Synedra ulna \\
\hline 2. & Pleodorina sp. & 2. & Rhopalodia gibba \\
\hline 3. & Tetraspora cylindrical & 3. & Gyrosigma kutzingii \\
\hline 4. & Palmella mniata & 4. & Pinnularia sp. \\
\hline 5. & Ourococcus bicaudatus & 5. & Neidium dubium \\
\hline 6. & Nannochloris bacillaris & 6. & Gomphonema sp. \\
\hline 7. & Schroederia setigera & 7. & Amphora ovalis \\
\hline 8. & Pediastrum boryanum & 8. & Diatoma sp. \\
\hline 9. & Pediastrum simplex & 9. & Cymbella cistula \\
\hline 10. & Pediastrum duplex & 10 & Diatoma vulgare \\
\hline 11. & Hydrodictyon reticulatum & 11. & Diatoma elongatum \\
\hline 12. & Coelastrum sp. & 12. & Navicula sp. \\
\hline 13. & Coelastrum cambricum & 13. & Navicula cupsidata \\
\hline 14. & Coelastrum sphaericum & 14. & Navicula cyclotella \\
\hline 15. & Chlorella sp. & 15. & Navicula radiosa \\
\hline 16. & Pachycladon umbrinus & 16. & Navicula reinhardtii \\
\hline 17. & Oocystis sp. & 17. & Cyclotella operculata \\
\hline 18. & Ankistrodesmus spiralis & 18. & Asterionella sp. \\
\hline 19. & Ankistrodesmus falcatus & 19. & Fragilaria sp. \\
\hline 20. & Closteridium lunula & 20. & Fragilaria capucina \\
\hline 21. & Closteridium longissima & 21. & Gomphonema olivaceum \\
\hline 22. & Tetradesmus wisconsinensis & 22. & Melosira granulate \\
\hline 23. & Spirolaenia condensate & 23. & Surirella ovate \\
\hline 24. & Closterium setaceum & & \\
\hline
\end{tabular}

observed phytoplankton community (Fig. 3). The minimum number was ( 3 per liter) during the month of September -October, 2005 at station B and maximum number (345 per liter) was seen during November-December, 2005 at station A (Fig. 2). The Euglenophyceae and Cryptophyceae on the other hand were relatively low in density and occupied fifth and sixth positions in dominancy with $5 \%$ and $1 \%$ contributions, respectively (Fig. 3). The minimum number of Euglenophyceae was observed ( 2 per liter) during May-June, 2006 at station A and maximum number was (132 per liter) found during November-December, 2005 at station B (Fig. 2). The Crytophyceae was not observed from the stations $\mathrm{B}$ and $\mathrm{C}$ during the months of November - December, 2006 but the maximum number of this group was recorded (38 per liter) from the sampling station C during the months of May -June, 2006 (Fig. 2).

The qualitative result of present study further made it clear that planktonic flora in Jaisamand lake was 


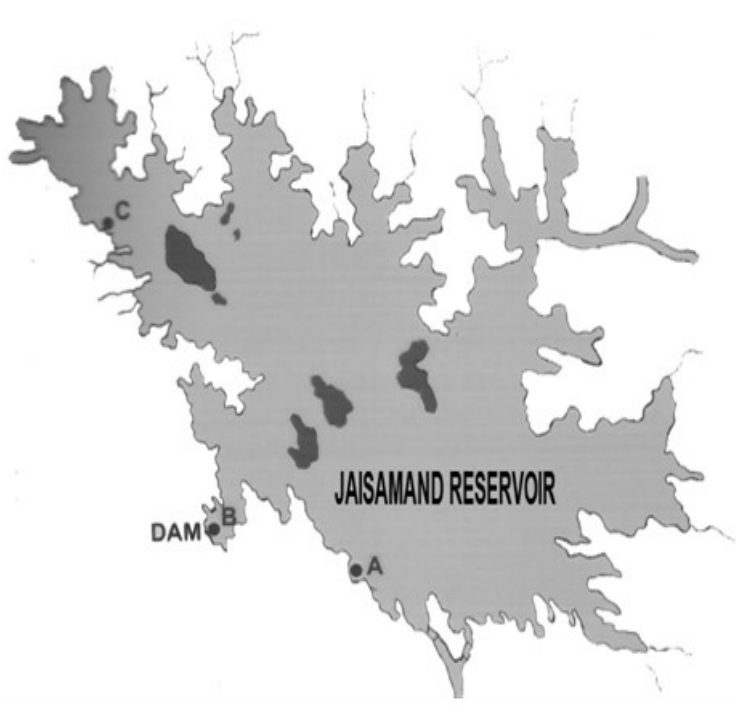

Fig. 1. Map of Jaisamand lake along with sampling stations (A, $B$ and $C$ ).

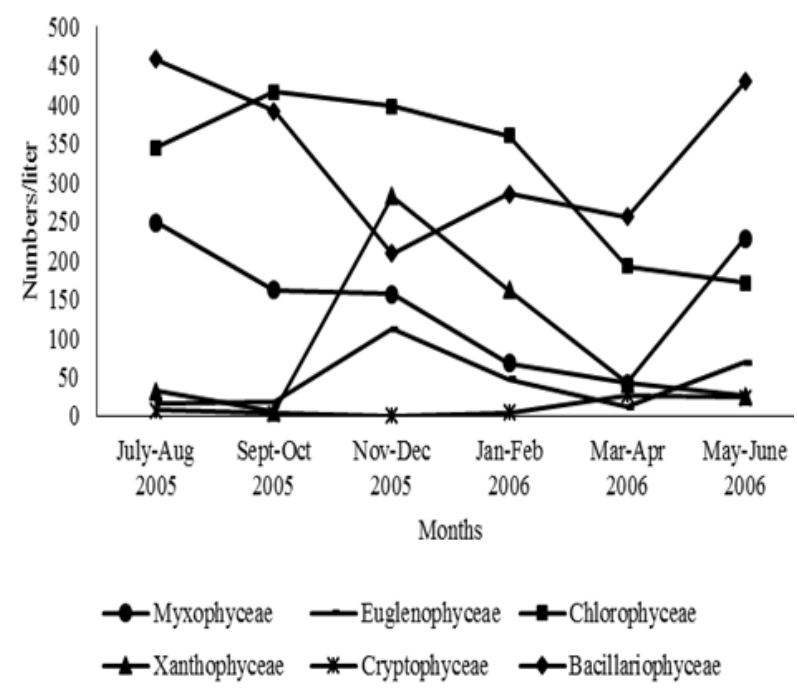

Fig. 2. Bimonthly distribution of phytoplankton in aisamanad lake.

contributed by six major groups i.e. Myxophyceae, Euglenophyceae, Chlorophyceae, Xanthophyceae, Cryptophyceae and Bacillariophyceae. These six groups comprises total 85 species in that 13 were from Myxophyceae, 5 from Euglenophyceae, 38 from Chlorophyceae, 3 from Xanthophyceae, 1 from Cryptophyceae and 23 belonged to Bacillariophyceae (Table 2).

The phytoplankton diversity of Jaisamand lake during 1981-82 was 52 species (Anonymous, 1984). During the present investigation, a total 85 species of phytoplankton were noticed. However, Rao and Durve (1987) have reported 52 genera out of which 25 belonged to Chlorophyceae, 12 to Bacillariophyceae, 2 to Euglenophyceae, 1 to Xanthophyceae and 12 to Myxophyceae from Jaisamand. Sarang et al. (2002) reported only 18 species of phytoplankton with dominance

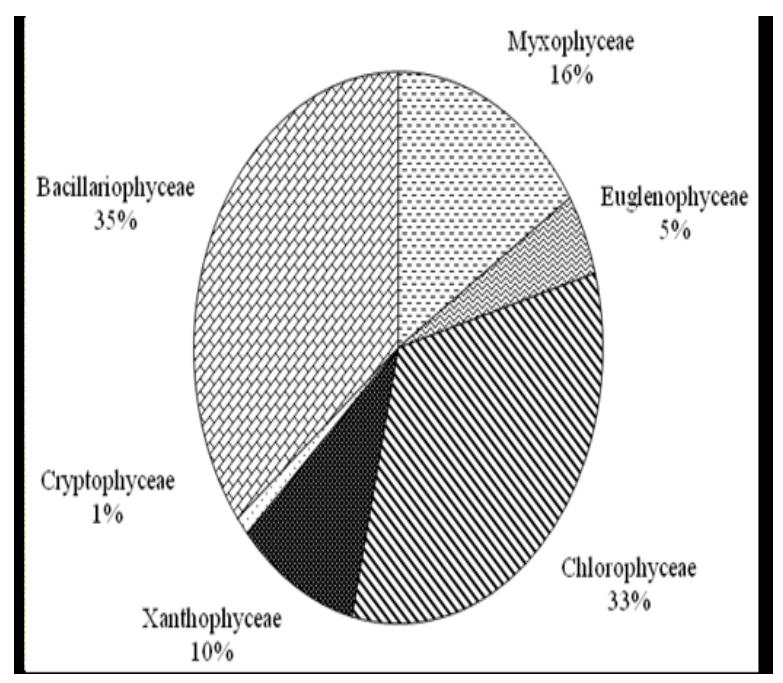

Fig. 3. Phytoplankton distribution in Jaisamand lake.

of green algae followed by blue green algae. Further, as regards relative dominance of different algal groups, Bacillariophyceae was followed by Chlorophyceae, Myxophyceae, Xanthohyceae, Euglenophyceae and Cryptophyceae in the present study which could be considered a desirable feature from the fisheries point of view. In Udaipur lakes receiving organic pollutants, Solomon (1994) reported the dominance of blue-green algae. Sarang (2001) reported dominance of green algae followed by blue green algae in Lake Jaisamand. Willen (1990), Yusoff and Patimah (1994) considered lakes as eutrophic on the basis of abundance of blue-green algae whereas Lake Jaisamand in the present study can not be considered eutrophic on the basis of observed planktonic densities. This is desirable feature from lake conservation point of view.

\section{Conclusion}

From the present study it can be inferred that the diversity and density of phytoplankton and are indicative of good productivity of Jaisamand Lake. The observed abundance of phytoplankton in lake was in order of Bacillariophyceae $>$ Chlorophyceae $>$ Myxophyceae $>$ Xanthophyceae Euglenophyceae $>$ Cryptophyceae. Further, is clearly depicted from this study that Jaisamand Lake maintained fairly good population of phytoplankton which is providing opportunity for sustaining more fish biomass having broad based feeding habits for achieving high productivity in this water body. The data generated may be used for managing scientific fisheries in this lake.

\section{ACKNOWLEDGEMENT}

The authors express their gratitude to the Dean, Rajasthan College of Agriculture and Director, Research, MPUAT, for encouragements and for providing necessary facilities for conducting this research. The help rendered by Dr Anil Kumar, 
Research Fellow, DAE-BRNS Project in plankton identification is gratefully acknowledged.

\section{REFERENCES}

Adoni, A.D. (1985). Work Book on Limnology. Bandana Printing Service, New Delhi pp 216.

Agrawal, S.C. (1999). Limnology, APH Publishing Corporation, New Delhi

Anonymous (1984). Energy flow, productivity and fishery potential of the lake Jaisamand. Final Report on ICAR Research Project.

APHA-AWWA-WDCF (1989). Standard methods for examination of water and waste water $\left(17^{\text {th }}\right.$ ed). American Public Health Association, Washington, D.C.

Beyruth, Z. (2000). Periodic disturbances, trophic gradient and phytoplankton characteristics related to cyanobacterial growth in uarapiranga reservoir. Sao Paulo State, Brazil. Hydrobiologia., 424: 51-60.

Busing, N. (1998). Seasonality of phytoplankton as an indicator of trophic status of the large perialpine "Lago di Garda”. Hydrobiologia, 369/370:153-162.

Chopra, Girish, Anil K.Tyor and Neha Aggarwal (2013). Biodiversity and community composition of phytoplankton in three lentic water bodies of different human use. International Journal of Environmental Science, 3(5): 1678-1388

Diazpardo, E., Vazquez, G. and Lopez-Lopez, E. (1998). The phytoplankton community as a bioindicator of health conditions of Atezca Lake, Mexico. Aquat Ecosystem Health and Management, 1(3):257-266.

Edmondson, W.T. (1965). Freshwater Biology. $4^{\text {th }}$ edition, John Wiley and Sons Inc. New York.

Ganai, A.H., Parveen, S., Khan, A.A. and Maryam, H. (2010). Phytoplankton diversity at Watlab Ghat in Wular Lake, Kashmir. Journal of Ecology and Natural Environment, 2(8):140-146.

Gayathri, N, Rajashekhar M, Kaneez Fatima, Vijaykumar K and Mahesh Baburrao Ratandeep. (2011). Hydrochemistry and plankton diversity of Tungabhadra Reservoir Bellary District, Karnataka. International Journal of Zoological Research, 1 (1): 01-07

Hassan Fikrat, M., W.D. Taylor, M.S. Mayson, Al-Taee and Hassan J.J. Al-Fatlaw. (2010). Phytoplankton composition of Euphrates river in Al- Hindiya barrage and Kifil city region of Iraq. Journal of Environmental Biology, 31: 343-350

Hecky, R. E. and Kling, H. J. (1981). The phytoplankton and the protozooplankton of the uphotic zone of Lake Tanganyika: Species composition biomass chlorophyll content and spatial-temporal distribution. Limnology and Oceanography, 26(3): 548-564

Jagadeeshappa, K.C. and Vijaya Kumara (2013). Impact of physico-chemical conditions on seasonal fluctuation of plankton diversity in certain wetlands of Tiptur taluk, Tumkur dist, Karnataka, India. Global Journal of Biology, Agriculture and Health Science, 2(4):143-150

Kemdirim. E.C. (2001). Check list of phytoplankton of Shedam reservoir in Plateau state. Nigerian Journal of Aquatic Science, 16: 61-66.

Lashkar, H.S. and S. Gupta (2009). Phytoplankton diversity and dynamics of Chatla floodplain lake, Barak Valley, Assam, Northeast India - A seasonal study. Journal of Environmental Biology, 30, 1007-1012.

Millman, M. Cherrier, C. and Ramastack, J. (2005). The seasonal succession of the phytoplankton community in
Ada Hayden lake, North Basin, Ames, Lowa. Limnology laboratory, Lowa state University, Ames, Lowa

Needham, J.G. and Needham, P.R. (1962). A guide for the study of freshwater biology. Holden Day Inc. San Francisco, 108

Park, S., M.T. Brett, E.T. Oshell and C.R. Goldman (2003). Seston food quality and Daphnia production efficiencies in an oligo-mesotrophic Subalpine lake. Aquaculture Ecology, 37: 123-136.

Pawar, S. K., Pulle, J. S. and Shendge, K .M. (2006). The Study on Phytoplankton of Pethwadaj Dam, Taluka, Kankhar, Dist. Nanded, Maharashtra, Journal of Aquaculture Boilogy, 21 (1): 1-6.

Pongswat, S., Thammathaworn, S., Peerapornipsal, Y., Thanee, N. and Somsiri, C. (2004). Diversity of phytoplankton in the Rama IX lake, a manmade lake, Pethumthani Province, Thailand. Science Asia, 30:261 $-267$.

Rao, P.S. and Durve, V.S. (1987). The structure of the phytoplankton community and the dynamics of its biomass in the lake Jaisamand, Rajasthan. Acta Phytochem Hydrobiology 15:79-91.

Reynolds, C.S. (1999). Phytoplankton assemblages in reservoirs. In: Tundisi, J.G. and Straškraba (eds), Theoretical Reservoir Ecology and its Applications. International Institute of Ecology. Brazilian Academy of Sciences and Backhuys Publishers, Leiden pp. 439-456

Sarang, N. (2001). Selected aspects Limnology and productivity of Jaisamand Lake, Udaipur (Rajasthan). M.Sc. (Ag.) thesis submitted to Maharana Pratap University of Agriculture and Technology, Udaipur.

Sarang, N., Sharma, L.L. and Devaradi, B. (2002). Impact of accidental Bio-manipulation on water quality of Jaisamand Lake: A case study from Udaipur (Rajasthan). Proceedings of XI National Symposium on Environment, Udaipur (Raj.), 5-7 June, 335-338

Senthilkumar, R. and Sivakumar, K. (2008). Studies on phytoplankton diversity in response to abiotic factors in Veeranam lake in the Cuddalore district of Tamil Nadu. Journal of Environmental Biology, 29:747-752.

Shashi shekhar, T.R., B.R. Kiran, E.T. Puttaiah, Y. Shivaraj and K.M. Mahadevan (2008). Phytoplankton as index of water quality with reference to industrial pollution. Journal of Environmental Biology, 29, 233-236.

Simciv, T. (2005). The role of plankton, zoobenthos, and sediment in organic matter degradation in oligotrophic and eutrophic mountain lakes. Hydrobiologia, 532: 69 -79 .

Solomon, I.J. (1994). Current Trends in Eutrophication of the Lakes Pichhola and Fatehsagar. M.Sc. Thesis Submitted to RAU, Bikaner.

Sridhar, R., Thangaradjou, T., Senthil, K., S. and Kannan, L. (2006). Water quality and phytoplankton characteristics in the Palk Bay, southeast coast of India. Journal of Environmental Biology, 27:561-566.

Subrahmanyan, R. (1971). The Dinophyceae of the Indian Seas. Part 2. Family Peridiniaceae. Marine Biological Association of India Memoir, 2: 1-334

Tas, B. Arif, and Gonulo, I. (2007). An ecologic and taxonomic study on phytoplankton of a shallow lake, Turkey. Journal of Environmental Biology, 28:439-445

Tiwari, A. and Chauhan, S.V.S. (2006). Seasonal phytoplankton diversity of Kitham lake, Agra. Journal of Environmental Biology, 27:35-38 
Vaulot, D. (2001). Phytoplankton.Centre Nationale de la Recherche Scientific et Universite Pierre et Marie Curie, Roscoff, France.

Walsh, C.J., Sharpe, A.K., Breen, P.F. and Sonneman, J.A. (2001). Effects of urbanisation on streams of the Melbourne region, Victoria, Australia. I. Benthic macroinvertebrate communities. Freshwater Biology, 46: 535-551.
Willen, T. (1990). Phytoplankton and eco-regions in Sweden. Distribution of species and life forms. International Verein Limnology, 24:655.

Yilmaz, Nese (2013). Phytoplankton composition of Sazlidere Dam lake, Istanbul, Turkey. Maejo International Journal of Science and Technology, 7(02): 203-211

Yusoff, F.M. and Patimah, I. (1994). A comparative study of a phytoplankton population in two Malaysian lakes. International Verein Limnology, 24:251-257. 